\title{
The missional church structure and the priesthood of all believers (Ephesians 4:7-16) in the light of the inward and outward function of the church
}

\begin{tabular}{|c|c|}
\hline \multicolumn{2}{|c|}{$\begin{array}{l}\text { Author: } \\
\text { Timothy A. van Aarde }{ }^{1,2,3}\end{array}$} \\
\hline \multicolumn{2}{|c|}{$\begin{array}{l}\text { Affiliations: } \\
{ }^{1} \text { Department of Humanities } \\
\text { Research, North-West } \\
\text { University, South Africa }\end{array}$} \\
\hline \multicolumn{2}{|c|}{$\begin{array}{l}{ }^{2} \text { Study Group: Ecclesial } \\
\text { Futures, The International } \\
\text { Association of Missions } \\
\text { Studies, United Kingdom }\end{array}$} \\
\hline \multicolumn{2}{|c|}{$\begin{array}{l}{ }^{3} \text { Biblical Interpretation, } \\
\text { Veritas College International, } \\
\text { Australia }\end{array}$} \\
\hline \multicolumn{2}{|c|}{$\begin{array}{l}\text { Corresponding author: } \\
\text { Timothy van Aarde, } \\
\text { timoman111@gmail.com }\end{array}$} \\
\hline \multicolumn{2}{|c|}{$\begin{array}{l}\text { Dates: } \\
\text { Received: } 15 \text { Nov. } 2016 \\
\text { Accepted: } 09 \text { Mar. } 2017 \\
\text { Published: } 18 \text { May } 2017\end{array}$} \\
\hline \multicolumn{2}{|c|}{$\begin{array}{l}\text { How to cite this article: } \\
\text { Van Aarde, T.A., 2017, 'The } \\
\text { missional church structure } \\
\text { and the priesthood of all } \\
\text { believers (Ephesians 4:7-16) } \\
\text { in the light of the inward and } \\
\text { outward function of the } \\
\text { church', Verbum et Ecclesia } \\
\text { 38(1), a1709. https://doi. } \\
\text { org/10.4102/ve.v38i1.1709 }\end{array}$} \\
\hline \multicolumn{2}{|c|}{$\begin{array}{l}\text { Copyright: } \\
\text { (c) 2017. The Authors. } \\
\text { Licensee: AOSIS. This work } \\
\text { is licensed under the } \\
\text { Creative Commons } \\
\text { Attribution License. }\end{array}$} \\
\hline \multicolumn{2}{|l|}{ Read online: } \\
\hline 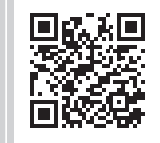 & $\begin{array}{l}\text { Scan this QR } \\
\text { code with your } \\
\text { smart phone or } \\
\text { mobile device } \\
\text { to read online. }\end{array}$ \\
\hline
\end{tabular}

The missional church is a new consciousness which has been raised for the missionary sending of the church in the West to be a witness for the Kingdom of God in its own context. The missional church has returned mission to the centre of ecclesiology. A structural functioning of the missional church and its relation to existing church structures are essential to rescue the missional church from simply becoming the latest fad. The present missional church conversation in advocating for an organic church structure undermines existing institutional church structures. A dynamic functioning church structure in which the inward and outward dimensions of the church's single ecclesiological structure are able to function in a cohesive unity is set out in Ephesians. The function of the gifted persons in the task of equipping of the believers to fulfil their missional calling, vocation and function is paramount to the healthy integration of the missional church model in existing mission and church paradigms and for it to function within the framework of existing church structures.

Interdisciplinary and/or interdisciplinary implications: The article suggests that a dynamic unity exists between the ecclesiology of the church and missional structure and function of the church. The article explores interdisciplinary implications from the fields of the New Testament and missiology.

\section{Introduction}

\begin{abstract}
One of the New Testament doctrines rediscovered by the Protestant Reformation - along with sola scripture, sola gratia and sola fide - which became of prime importance for the life of the church was 'the universal priesthood of all believers'. (Roldán 2004:151)
\end{abstract}

It is the motivation of missions in both the Reformed and Lutheran traditions. The Reformed and Lutheran missions are based on sola fide, solus Christus, sola gratia and sola scripture ('faith alone', 'Christ alone' and 'scripture alone'). It is because Reformed and Lutheran missions share an overlap in theology of missions that these two traditions are brought into dialogue in the article. The priesthood of the believers has been central to both these traditions since the reformation and has profound implications for the missional church. The priesthood of believers can make possible a 'missional ecumenism' yielding a coherent exercise of the priesthood of believers by various church traditions through making the missional church paradigm, a unifying church mission's model. Darrel Guder (2000) writes, '... we have forgotten how to read the New Testament as it was intended to be read, as equipping of God's people for mission (p. 188)'. The traditional division between priest or pastor and lay people, who are the true priesthood (1 $\mathrm{Pt}$ 2:9), has been broken down so that all who confess Christ as Lord are 'priests' and called to a missional vocation (Eph 4:1-2):

We still need priests and pastors, as we need other leadership functions (teacher, evangelist, apostle, prophet - Eph 4:11), but the basic structure of the local church and for mission is the priesthood of all believers. (Balia \& Kim 2010:120)

The church has lost its function and calling to society and:

the church must again become a community in which all members, equally, encourage each other to discover and to develop their gifts and ministries in the countless areas of human existence where transformation and renewal are needed. (Balia \& Kim 2010:120)

One of the criticisms of the missional church is that it does not mention ecclesiastical structures that would prepare the laity for their callings (cf. Goheen 2002:486, 488 in Ott, Straus \& Tennent 2010:201). In Ephesians 4:1-16, an ecclesial structure for the church to be missional, is developed. 
It is an interaction and relation of internally and externally orientated roles and functions to empower and equip the church structure to be dynamic. Karl Barth (1978) writes of the church: 'The concept of the Church is the concept of a dynamic reality' (Barth 1978:192).

\section{The problem}

'Of all the doctrines recovered by the Reformation, "the universal priesthood of all believers" is still far from becoming historical reality' (Roldán 2004:152). The reason that the priesthood of all believers has not been effectively realised is because a sharp differentiation is made between the clergy and laity in the institutionalised church (cf. Roldán 2004:152). The resolution will not be achieved through the relation of the institutional and the organic church, but through a dynamic relation of the inward and outward life of the church in the missional church concept ${ }^{1}$. 'The missional church conversation also rightly identifies the dangers of overly institutional understandings of the church, which tend to be self-serving and undermine its missionary calling' (Ott, Strauss \& Tennent 2010:199). One of the arguments made against the missional church movement is that it advocates for local and global mission which has no substantial theological basis. 'Berkhof believes that ecclesiology as a whole needs to be rethought from the standpoint of the church's orientation to the world' (Berkhof in Goheen 2000:271)2.

\section{The origins of the missional church}

The contributors to the research project which produced the monumental book title, Missional Church, who coined the term, 'missional', were influenced and shaped in their thinking by the language of Vatican II, which stated, 'The pilgrim church is missionary by her very nature'. This was the critical reason for using and understanding the word 'missional' (cf. Armstrong 2010:154). It was Paul VI's contribution of 'Evangelii Nuntiandi' that re-envisioned the understanding of evangelisation which comes from the example of Jesus Christ, and the church in each location as the responsibility of assimilating the essence of the Gospel message and transposing it (cf. Sunquist 2013:156), which gave an impetus to the missional church movement. It identified three major aspects of evangelisation: the verbal proclamation of the Good News, a life of personal witness to the Good News and transforming social praxis in accordance with the Good News. This has been a major contributing source from which the missional church concept has developed, in which the social praxis that is envisioned is neither merely an ethical imperative of the Gospel nor is it a form of pre-evangelisation, but part of the process itself. The distinction between evangelisation and missional is that missional is to bring the Good News into all strata of

1.Beyond the necessary and important elements of institution and organisation, the church is above all things a community, a dynamic reality and an event, something that happens (cf. Roldan 2004:159).

2.Bekhof speaks of the threefold character of the church. The church is an institution, a community and the church is to be orientated to the world (cf. Berkhof in Goheen 2000:271). humanity, and through its influence transforming humanity from within and making it new (cf. Sunquist 2013:156). The distinction has been expressed concisely by the core group for the theme 'Forms of Missional Engagement' of Edinburgh 2010:

The word missionary refers to the specific mission activities of the church, whereas the word missional is related to the nature of the church, as being sent by God to the world. (Balia \& Kim 2010:120)

\section{The meaning of missional}

Missional means that it is not the ordained pastors and missionaries who step out on behalf of all Christians, but it is the call of all Christians to actively live out a missional lifestyle through service, through a lifestyle which affirms a conscious decision to proclaim the Gospel. It is the calling of the entire body of Christ to become participants in God's mission and his purposes. Ephesians 1:9-10 has been identified as a text which helped the Ephesians to 'awaken to what was happening around them as well as how God might be calling them to shape their lives' (Roxburg 2009:98). 'It is time to move beyond those "pastrocentric" models in which the whole ministry rests in the hands of one or two people, while others are "stone guests"' (Roldán 2004:173). It is both the calling of the Church of the North and South to become missional. It means that all believers in the church are to commit themselves to the task of missions and to be missional by actively and intentionally witnessing to Christ in their local context. The traditional approach to the involvement of the church in its local context has been that the church commits itself to the particular activity of proclamation by expecting and requesting that pastors and missionaries engage the unbelieving culture and world on behalf of all Christians. The missional approach is a rediscovery of the priesthood of all believers and the task committed by the Trinitarian God. A fallacy of the missional church conversation is that it no longer advocates that the church should send missionaries and that everything the church does is to be mission. Missional is a way of being present in the world, to be the incarnation presence of Christ to our neighbourhoods. It is to the extent that the church actively reaches out to its neighbourhood that it will be recognised as a relevant presence in the community. The universal priesthood of all believers means that every Christian is called to his neighbourhood.

The term 'missional', as the term Missio Dei, has been used for all mission's activities, but without a biblical grounding and development of the concept. 'It seems that everyone is missional now' (James 2013:253). In Ephesians 4:1-16, the dynamic way of living the Gospel is expounded and stressed, not as a static proposition but as a concept best expressed by the term missional. 'The missional mind-set changes everything' (James 2013:254). It involves learning to think and live missionally ${ }^{3}$. The distinction between missions and missional is that the church by its very nature is missional. 'The word missional represents a fresh, profoundly theological, Missional Community' in 'The Community of the Word' (Guder 2000:10). 
and immensely practical way to think about the church in a time of transition' (Armstrong 2010:160). One of the dangers which has to be guarded against in the missional church moment is its separation from denominational churches and their traditions, in which case it will have no impact on the traditional church and end up as a stream of the emergent church ${ }^{4}$.

Lesslie Newbigin (1995) asked essential questions about what it means to be the church, and the culture in which we live. He spoke of a three-way conversation between the Gospel, the church and the culture in which we live (Figure 1). The integration of all three elements identified by Newbigin is indispensable and required to be present for a biblical idea of mission and from which the idea of missional developed. This root is critically important because the Gospel has to be central in the missional church movement for it to be authentic to its historical roots.

\section{Becoming missional}

The confession of Ephesians 4:4-6, which is the confession of the universal church, is:

a renewed determination to manifest together 'the hope of [their] calling' (Eph 4:4) in order to share more fully in the plan of salvation for the reconciliation and gathering up of all things in Christ (cf. Eph 1:9-10). (Balia \& Kim 2010:214)

The missional calling is for every believer to participate in the fulfilment of God's plan for the church and the cosmos. Central to this is the concept of reconciliation as a means of challenging the boundaries between denominations which have become normal and acceptable over the course of time. 'The road to reconciliation must place a high value on faith held in common and on mutually accepted values between divided churches' (Marsh 2005:56).

\section{Definition of missional terms}

A variety of gifts have been given by the Holy Spirit to equip every Christian to perform a particular missional function in

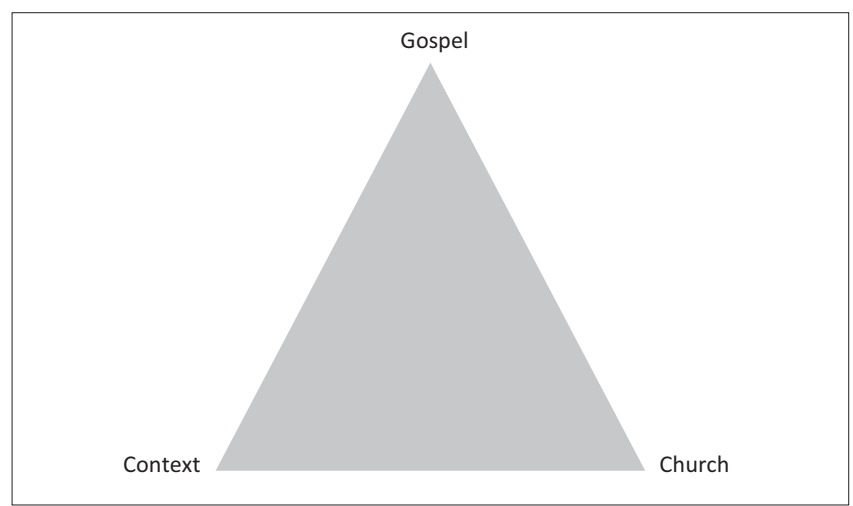

Source: Roxburg, A.J., 2009, Introducing the missional church. What it is, why it matters, how to become one, Baker Publishing House, Grand Rapids, MI, p. 72

FIGURE 1: The missional conversation.

4.The category of emergent and the imagination of missional are two different things (Roxburg 2009:54). response to a diversity of human needs in the world. This missional function is building missional bridges over which the Kingdom of God can penetrate into the life of people and give them new meaning. 'The church can only respond to the challenge of integral mission when it exercises the priesthood of all believers' (Roldán 2004:172) ${ }^{5}$. The term 'integral missions' has been used in association with the mission of the church. For this reason, the term 'integration' is preferred and creates space for the integration of different denominational views of being missional church into the denominational framework and a local church. 'Integral missions demand the "declericalization" of ministries and a "laicization" of the clergy" (Padilla 2004:45). Integration does not advocate the removal of these distinctions, but for denominational boundaries to become more flexible. This will result in the sharp distinction between 'religious life' and 'daily living' and between 'the sacred' and 'the secular' to be better integrated. Padilla uses the term 'integral mission' for the vision of the whole church with every member as agent engaged in all areas of human life and creation. 'Integration' involves all denominations involved in mission and moving towards becoming missional. The term contextualisation has been used for the missional church which leads to confusion because its original use was for the transposition of the Gospel into foreign missions contexts. It has been applied to the missional church as there was no other appropriate term. The missional engagement with society takes place through missional negotiation in the local context rather than through contextualisation, which involves the translation of the Gospel into a foreign cultural context. Contextualisation is used for 'both the message of the Gospel and the life of the church in specific cultures' (Ott, Strauss \& Tennent 2010:102). The missional church conversation has used it primarily for the life of the church opening up the possibility of a confused meaning. 'Contextualization is not limited to missionaries and preachers spreading the Gospel' (Sills 2010:200), in this sense it can be used. However, it is specifically used in missions to correct the lack freedom of self-expression or contextualisation of the past in which churches on the mission field often became clones of the sending denominations and so in this sense is inappropriate. Every believer is called to practice missional negotiation between the culture of his church and local culture, whereas contextualisation belongs primarily to the field of missions. The missional vocation is for every member of the church to engage his or her local context through missional negotiation in all areas of society, human life and creation.

\section{The shift from the church-in-missions of the 1960 s to the missional church of the 1990s}

The idea of the church-in-mission is attributable to Lesslie Newbigin. The church-in-missions is based on the mission's function of the institutional church (cf. Marsh 2005:47). The building block upon which the church-in-missions was built was the reformational understanding of different spheres of

5.Integral missions include among other activities, evangelism, baptism, teaching, counselling, liberation, restoration, compassion and social action (cf. Roldán 2004:173). 
life and the calling of every believer to direct them towards the will of God. 'According to Lesslie Newbigin, institutional churches should "train, support and nourish" their members to enable them in their secular work' so that 'groups of Christians working in the same sectors of public life' can meet 'to thrash out the controversial issues in their business or profession in light of their faith' (Newbigin in Hoksbergen 2011:100-101). The reformational understanding was that the church's calling is to penetrate all spheres of life with the Gospel. Visser (2011) writes:

In the Word that became flesh in Christ, we received an abundance of tools to distinguish between righteousness and unrighteousness; and the biblical message penetrates all spheres of life to direct them toward the will of God. (p. 40)

The church-in-mission paradigm endeavours to address political problems in the public sphere based on a Reformed ecclesiology, which was based on the distinction between what Abraham Kuyper called the church as institute and the church as organism' (Hoksbergen 2011:100):

On the one hand is the institutional church, made up of elders, deacons, worship patterns, and buildings. On the other hand is the church-in-mission, Christ-followers everywhere who work redemptively in all areas of life in response to God's call on their lives. (Hoksbergen 2011:100)

This has led to the idea that missions belong exclusively to the ordained ministry. This distinction between the church as institute and organism with its members functioning as the organic church sent out on a mission by the institutional church has informed the Reformed perspective of missions through the influence of Abraham Kuyper. The division is apparent in the demarcation of certain functions to the church as institute and others to the believers as the organic church. The result of this dualistic functionalism is that the Gospel seldom transforms the society ${ }^{6}$. Church members go to the church, the public institute, but when they leave they enter the world of the private sphere where their faith is private. In the view of Hoksbergen, the role of the organic church is to interpret the insights from the institutional church for businesses, households, civil society and government, all the arenas that the organic church spreads (cf. Hoksbergen 2011:102) an illustration of the dualism. In this fictional dichotomy, the power of interpretation belongs to or with the institutional church and the organic church merely applies the interpretation. The sole nourishment and equipping of the organic church in such a dichotomy is:

through the preaching that the community is trained, supported, and nourished to think with a renewed mind, focused on kindness, compassion, patience, justice, stewardship, and God's special heart for the poor, members go into the world and work for social transformation. (Hoksbergen 2011:101)

The result is that because of such a fictional dichotomy the church does not fulfil its prophetic call and task, because it is the sole calling of the church offices to make pronouncements about the social, economic and political disorder in society. The missionary role of the laity in which this view is perpetuated is that the believer is to be a hidden presence in society. The laity function like leaven which works through the bread. Newbigin was a prophetic voice in his time when he made the point that:

the major role of the Church in relation to the great issues of justice and peace will not be its formal pronouncements but in continually nourishing and sustaining men and woman who will act responsibly as believers in the course of their secular duties as citizens. (Newbigin 1989:139 in Hoksbergen 2011:102)

The church has to rediscover its unity and function as a flexible, dynamic and Holy Spirit energised community. It is the rigid separation of the institutional and organic church, derived from the political theory of Abraham Kuyper $^{7}$ in Reformed missions which has inhibited the church-in-missions from having a transformational impact on society ${ }^{8}$. The missional church is a prophetic, flexible, dynamic, Holy Spirit moment in which the church can be revitalised through missional engagement with society. It is as every believer functions as a priest that the original missionary spirit of the Protestant Reformations will be recovered. The letter to the Ephesians does not function with an ecclesiology of the institutional and organic church, but with the distinction between the universal and invisible church. The church as set out in Ephesians is universal and invisible and functions organically. "The church is both visible and invisible' (Armstrong 2010:111). Armstrong warns that 'without this understanding we can easily move away from mission into a protective institutional organisation that can become racist, nationalistic, or misogynistic' (2010:111). It was the loss of the mission's function of the church which led the confusion of the role of state and church in the apartheid era of South Africa. The church functioned as an institution of the state and did not function as an organism ${ }^{9}$. The inward and outward functioning of the church is an empowering relation, which is the framework the letter to the Ephesians provides for a church to function effectively as a missional church. The relation between the church as institute and organism is necessary for the relation of church and society as Andrea Z. Stephanou's writes:

However, political theology that promotes institutionalisation as a theological concept will encourage the church to have an institutional role that is independent of the state and contribute to building bridges between the Church and society. (Stephanou's in Andrew \& Kim 2010:221)

7.Political theology requires a relative and flexible concept of identity and needs a theology that believes that no one owns the absolute truth (cf. Stephanou's 2010:220).

8. Hoksbergen (2011) identifies the task in terms of a dualism between the institutional church and the organic church. "I believe the institutional church in the Reformed tradition can find a way to keep these vital issues before the members and thus foster a lively and productive conversation in the organic church' (Hoksbergen foster a lively and productive conversation in the organic church' (Hoksbergen
2011:103).

9.It was because the organisation and organic nature of the church was isolated and separated from the universal and invisible framework that the church in South separated from the universal and invisible framework that the church in South
Africa moved away from missions into a protective institutional organisation in the Africa moved away
pre-apartheid era. 


\section{A rediscovery of the organismic function of the church in the missional paradigm}

In the letter to the Ephesians there is a:

paradigm shift from the Church's mission to God's missions, and from a mission to 'those far away' to 'those who are near', implies a renewed focus upon the local context and the primary role of the local church-in-mission. The local church is always the actual expression of the worldwide church, the people of God in the local context. (Taylor \& Cho in Andrew \& Kim 2010:314)

The missional church paradigm is a view of the church as a dynamic functional church, never a static entity ${ }^{10}$. In the missional church movement, the church is a dynamic reality and event. It is about reaching out through holistic ministry to the local community and beyond. The modern day migrant people movement means that the nations and cultures have moved in next door. The laity and their task of the priesthood of believers is to participate in God's glocal dimension of the Missio Dei by participating and fulfilling the Great Commission by going next door. This does not mean that the church no longer has a mission, but that it is on mission with God both to the nations and next door. In 1967, Roman Catholic Ronan Hoffman called for missions' structures to dismantle-for every church member should be a 'missionary' (cf. Sunquist 2013:155), this, however, was not realised. The missional call is not to dismantle missionary structures, but to dismantle institutional structures in the church which prohibits the church from reaching out to its next door neighbours. Dismantling these structures, however, does not mean that the biblical model of deacons, elders and pastor is to be identified as the institutional model as J.F. Engel and W.A. Dryness do and that it is to be replaced with the church as an organism model ${ }^{11}$.

Essential to the idea of the missional church is the priesthood of the believers. It is a foundational concept which empowers a congregation to function missionally. A missional church structure which is functional is set out in Ephesians 4:1-16. It is captured and expressed by the maxim of Barth that in the church there cannot be a sharp distinction between 'ecclesiastics' (ordained) people and 'secular' (lay) people, 'because no member of the church exists who is not all of that in their own right' (Barth 1978:209) ${ }^{12}$. The missional church is based on the idea that God is at work in the world, and that as Christians go out into the world, God has gone before and is already at work through the Holy Spirit. It involves discerning the work of the Spirit in the lives of people. The role of the missional church is to be an incarnational presence in the community, in the formation of a Spirit-led and relational community.

10.The paradigm shift from the Church's mission (-1950s) to the mission of God (1960s-1990s), Missio Dei and missional church is not a replacement of these paradigms (1990s-).

11.'We argue that the institutional form of the church has distorted its own nature as the living body of Christ in the world and become inflexible. It is more like a living and responsive organism than an organization' (Engel \& Dryness 2000:117).

12.The clergy and laity are members of the people of God. And although it is impossible to escape this differentiation, the emphasis is to be placed on members of the people of God.

\section{A biblical theology for the missional church: The Kingdom of God, the Gospel and preaching}

The biblical theology of the priesthood of believers is central to the function of the 'missional church' paradigm. The priesthood of believers was a teaching rediscovered in the reformation which the missional church conversation has not sufficiently drawn upon. The priesthood of believers has always been central for the church, and so it is fundamental for the missional church to be able to function as a missional community. To be missional is a new consciousness to be witnesses for and of the Kingdom of God in our glocal context, a globalised world in which the local and global meet and affect each other. The Kingdom of God is in essence expressed in and through the priesthood of believers. In missions and missional, the Kingdom of God is revealed through the act of preaching, кń only presence. The preaching of the Word and mission are essentially the means by which the Kingdom of God is revealed. It is through preaching which is directed both inwards and outwards that the Kingdom of God is expressed through the church, by means of the $\kappa \dot{\rho} \rho \gamma \mu \alpha$, the inward

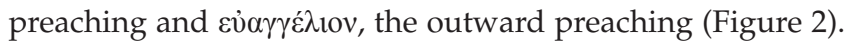
It is through the necessity of both these forms of preaching that the church is both an expression of the kingdom and an instrument of the kingdom in service of the plan of God, oikonomia of God (Eph 1:10).

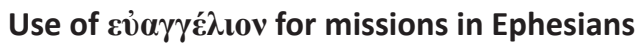

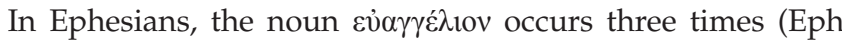
$1: 13,3: 6,6: 19)$, and the verb $\varepsilon \dot{v} \alpha \gamma \gamma \varepsilon \lambda i \zeta \omega$ for sharing the Gospel to outsiders occurs two times (Eph 2:17, 3:8), once in a form found only in Ephesians 3:8. Gospel preaching, $\varepsilon \dot{v} \alpha \gamma \gamma \varepsilon \lambda i \zeta \omega$, is generally preaching which is associated with the external proclamation of the Gospel and is generally directed at those who are outside the church. 'In Ephesians 6:15 Paul draws from the $\varepsilon \dot{\alpha} \alpha \gamma \varepsilon \dot{\varepsilon} \lambda$ lov word group to describe the necessity of ordinary believers to be prepared for Gospel proclamation' (Plummer 2006:27). The laity are called to the task of the proclaiming of the Gospel, to put on the shoes of the Gospel

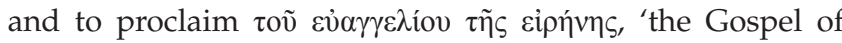
peace', wherever they go and place their feet (Eph 6:15).

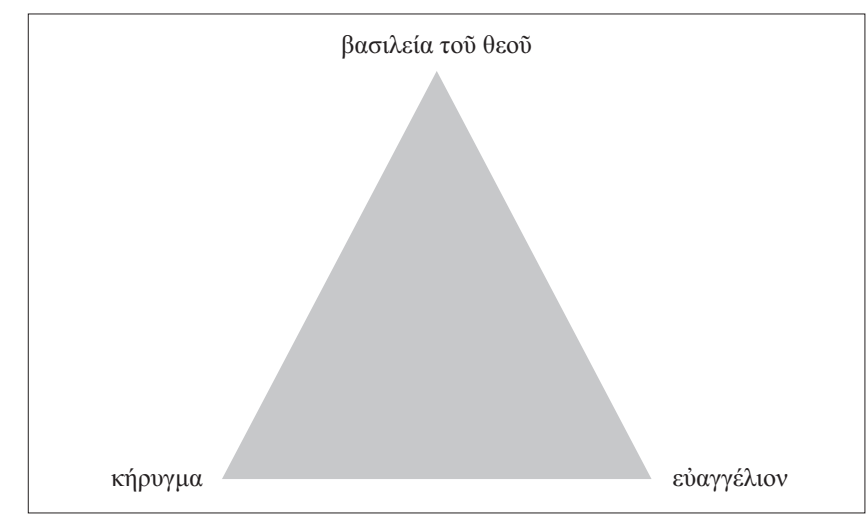

FIGURE 2: The Kingdom of God is proclaimed and revealed through inward and

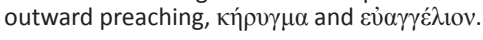




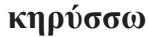

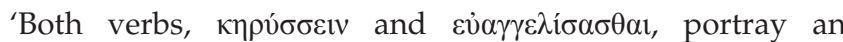
outward activity of preaching the Gospel to the world' (Schultz 2009:16). It is used 61 times in the New Testament, 20 in Paul (Rm 2:21, 10:8, 14, 15; 1 Cor 1:123, 9:27, 15:11, 12; 2 Cor 1:9, 4:5, 11:4, Gl 2:2, 5:11; Phlp 1:26; Col 1:23; 1 Th 2:9; 1 Tm 3:6;

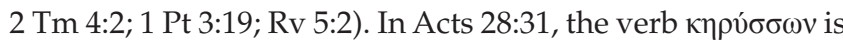
used for outward preaching and it is associated with $\pi \alpha \rho \rho \eta \sigma i \alpha$ in Acts 28:31, indicating that it is missionary in nature. In the Gospel of Matthew, the verb is used for the preaching outside of the church and to communicate the content or Gospel of

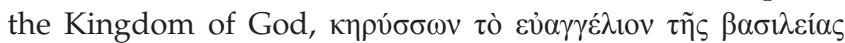

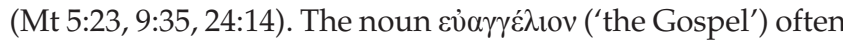

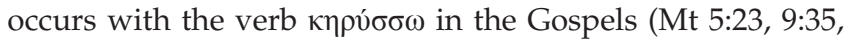
24:14, 26:13; Mk 1:14, 13:10, 14:9, 16:15), thus indicating the outward direction of the form of preaching.

\section{The inward and outward dimensions of the one church structure}

The church has a missionary and missional dimension to its one church structure. The mission's dimension of the structure is: 'The congregation as a local come-structure and the mobile "missionary band" as a mission-specific go structure' (Jørgensen 2012:46).

\section{Oikovouía}

The term oikonomia is used by Paul for stewardship of the gospel in both the local 'come' structure (1 Pt 4:10) and the 'go' structure (1 Cor 4:2, 9:17; Eph 3:2, 9). The term oikonomia is thus used for a local and global missionary structure, in the local for the role of the pastor in local missions (1 Tm 1:5) and/or the elders in local missions (Tit 1:7), and is directed outwards towards the world (1 Cor 4:2, 9:17; Eph 3:2, 9). The term oikonomia is also used of believers and the use of their gifts (1 Pt 4:10-11), which means they are stewards of the rich grace of God and to be involved in the missional church, which is directed both inwards and outwards. The phrase, 'whoever speaks, is to do so as one who is speaking the utterances of God' (1 Pt 4:11) indicates that a verbal element is implied, but distinct from preaching.

\section{Оїкобонѝ}

The term oikodome as a nomen actionis communicates both the building out and building up of the church. 'The phrase

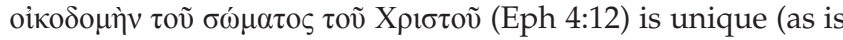

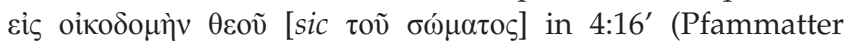

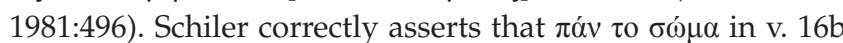
no longer refers to the Church, but to the worldwide body. The Church then in its activity of oikodome, self-edification and other-edification accomplishes at the same time the growth of the world-body into Christ (cf. Pfammatter 1981:496-497). The 'gifts' (Eph 4:11) function to build the church up and out for works of service directed to those in and outside of the body of Christ by the believers (Eph 4:12). Growth is measured in terms of maturity and fullness, increased impact (Eph 4:13,15-16). The term oikodome is an expression of development, but there is no limitation or specification of nature of the development in Ephesians 4 as being of a certain kind. About the growth Van Engen (1996) writes:

This growth in greater oneness through the incorporation of other members into the body (numerical growth), growth through spiritual development of the members of the body as they exercise their gifts for the sake of the world (organic and spiritual growth), growth through the increased impact of the body of Christ in the world to which it has been sent (growth in diaconal service), and growth through an enhanced understanding of the lordship of Christ in the church, which will prevent us from being 'tossed by the waves and whirled about by every fresh gust of teaching'. (4:14 NEB - theological growth) (p. 109)

The building up is so that the church community might live out and embody the salvation that has been accomplished (Eph 4:11-16) (cf. Goheen 2011:179). The building up is for the sake of the community and the world (cf. Goheen 2011:180) and so oikodome is not an end itself. It would be a mistake to identify oikodome purely with sanctification, growth towards maturity, separating the tasks of evangelism and sanctification in Ephesians 4:11-16.

\section{The functioning of the missional church}

The missional church movement makes a distinction in terms of function and office; it places the emphasis on the function of the ordained ministry instead of the office. The missional church specifically addresses lines of hierarchical distinction between the ordained ministry and laity in order to promote a dynamic functional church structure. It consciously and selectively chooses neutral and inclusive language which empowers the believers for their task and calling in the world. The distinction between the ordained clergy and laity is maintained when the power and right of interpretation are confined exclusively as the right of the institutional church and the ordained ministry. The task of the church is to equip and empower all believers to interpret the Word of God and to liberate the community from a formalistic relation of the institutional and organic church structure. The task of the

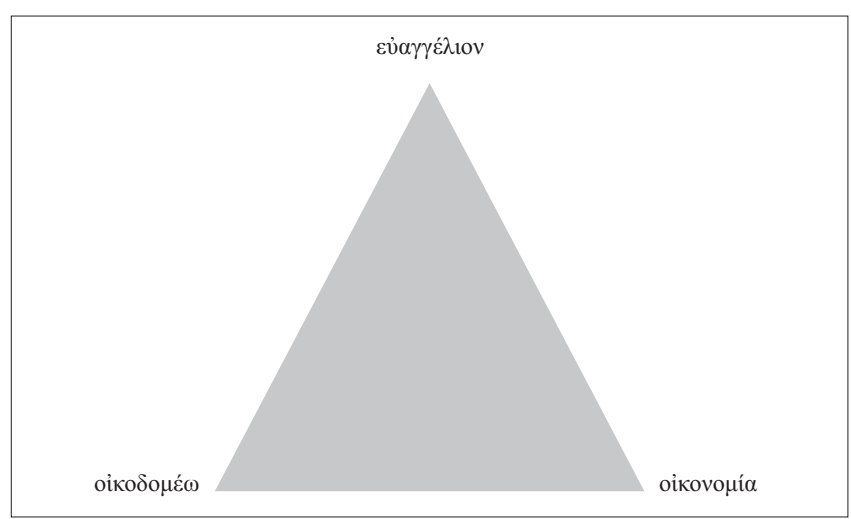

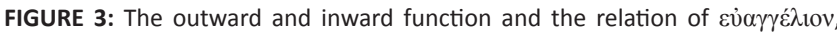

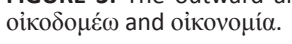


'gifts' or 'gifted ones', language to be preferred to the ordained ministry and their role, is to equip the believers to use their 'gifts' and to empower them to be able to interpret God's Word. The believers are to be instilled with the ability and confidence that they are proficient and capable of the missional proclamation of the Word of God in every sphere of society. The church structure advocated in Ephesians 4:1112 is a functional church structure which does not minimise the importance of the church-in-missions, but gives equal priority to work in the society and the work of building up of the Christian community (Figure 3). It is through the inner equipping and building up of the body that the church is able to engage in missional outreach in society. In Ephesians 4:7-16, the inward equipping and the building out are related together and function together in a dynamic way.

\section{The missional functioning of the priesthood of all believers}

The missional mandate considers how to strengthen the missional aspects of the training and formation of every member of the church (Balia \& Kim 2010:266). The priesthood of believers are by their baptism commissioned 'to proclaim God's marvellous acts' to the world (cf. Balia \& Kim 2010:26). The 'gifts' and the laity both function within a community to build up the body of Christ. In the missional model, the function of the 'gifts' is to equip the laity so that they can fulfil their calling both within and outside of the church. The biblical image of the body of Christ is an image of the missional (emphasis added) ecclesia which has a networking nature (Eph 4:12) (cf. Balia \& Kim 2010:130). Wright (2010:216) writes about the gifts that 'he may well be referring to the wider apostolic (missionary) role, especially in planting and nurturing churches in the first place', but this view identifies the gifts exclusively with missions. In the missional church, the emphasis is not upon missions but being an incarnated missional presence. William Saayman (2010:14-15) correctly advocates that it is essential to maintain the term missionary for those engaged in foreign missions in a missional congregation.

\section{The missional calling of the believer (Eph 4:1-2)}

It would seem on the basis of both Ephesians 3 and 4 that it is both the 'gifts' and the laity, ordained and ordinary believers, who are to continue to do the work of the ministry. Markus Barth (1974) correctly observes:

all the saints (and among them each saint) are enabled by the four or five types of servants enumerated in 4:11 to fulfil the ministry given to them so that the whole church is taken into Christ's service and given missionary substance, purpose, and structure. (p. 479)

He writes from the perspective of 'the traditional distinction between clergy and laity does not belong in the church' (Barth 1974:479). Barth only mentions one dimension, the missionary task, but in Ephesians both the missionary and missional calling of the church is set out. It is as the church fulfils its missional calling and task that the distinction between the clergy and laity will result in the church functioning together in a dynamic unity. In Ephesians 4, a missional purpose is identifiable (cf. Eph 4:1-16). The missional purpose and interpretation of Ephesians 4:1-16 challenges the aristocratic-clerical - ecclesiastical exposition of Ephesians 4:11-12 (cf. Barth 1974:479). The calling to be missional does not mean that every Christian is to understand himself or herself as a missionary, but that every Christian has a missional calling and task. 'The people of God are to be a servant people, ministering actively but humbly according to their gifts in a world of alienation and pain' (Stott 1979:167).

\section{The equipping of the saints to function in a missional church}

There has been a long standing and unresolved debate as to whether the 'gifts' in Ephesians 4:11 in relation to 'the work of the ministry' indicate that these 'gifts' or 'gifted ones' who themselves fulfil the work of the ministry are offices which continue in the church, the Pentecostal and Charismatic view, or if they are functions in the church. As it is the 'work of ministry' which is carried out by the believers, what is in view cannot be the continuation of the offices, but must be the function of these 'gifts', the role of equipping the saints to do the work of the ministry. It is the believers who fulfil the missional function in society and the 'gifts' or 'gifted ones' role is to equip them to do so. These 'gifts' could be missionaries who equip the believers to fulfil their calling, but this does not seem to be the case. In Ephesians 4:11-12, what is in view is the dynamic functioning of both 'gifted ones' and the believers, 'the gifts' equipping the believers to fulfil their missional calling:

If a comma is put between the first and second concept, no doubt is left that the gift of the ministries has a double object: not all the saints benefit from it, but only selected ministers carrying out the work of building the body. (Barth 1974:478) $)^{13}$

But if no comma is placed between the first and second parts of $\mathrm{v} .12$ then the ministries are given to the church in v. 12 for the saints to be able to carry out the work of the ministry, 'the work of service' and 'the building'. The implications if this interpretation is not followed are twofold according to $\mathrm{M}$. Barth (1974):

the layman are ultimately only beneficiaries, and the benefits of the clergy's work remains inside the church - though people and power outside the church may witness the clergy's successes and failures. (p. 479)

Furthermore, if 'the work of the ministry' functions only within the body, then diakonia in the context is limited and directed only towards other believers in the body. A church which serves only its own is an exclusive community and has become detached from its role and involvement in society. The view that it is the laity who are to perform the 'works of service' refutes the assumption that the bulk of the church

13.Armitage Robinson (in Stott 1979:166) argues that "the first comma "ithe fata comma") - which is "without linguistic authority but with undoubted ecclesiological basis" -must be erased'. Stott (1979) writes that if the comma is allowed to stand that 'this interpretation has an aristocratic, that is, a clerical and ecclesiastical flavor, it distinguished the (mass of the) "saints" from the (superior class of the) officers of the church' (Stott 1979:166). 
members are reduced to the rank of mere consumers of spiritual gifts, and the notion that church as a whole must strive primarily for a 'building-up' which benefits itself only (cf. Barth 1974:479). The identification of apostle, prophet, evangelist, pastor and teacher as functions best fits the missional church context than missionary offices.

\section{The apostolic equipping function}

It is Calvin who argues that the biblical 'office' of apostle (Eph 4:11) was charged with the expansion of the church (cf. Pratt, Sills \& Walters 2014:107). The 'apostolic gift', a special leadership gifting, enables the church to be outward looking and stimulates the church to have a vision for the neighbourhood as well as a global vision and desire for kingdom expansion. The desire of those with an apostolic or missionary gifting want to see the church come to the stature of the fullness of Christ, to a mature corporate body, and for all the gifted persons in the church to fulfil their function in the church. It is a misconception that it is solely the task of the teacher and pastor to mobilise the church for mission and to be missional. It is the task of persons with apostolic leadership gifting to mobilise and lead the church into missions, but also to guide the church to be a missional presence in the community. The term 'apostle' in Ephesians 4:11 is used with the task of equipping others to proclaim the Gospel to the Gentiles or unbelievers. In 2 Corinthians 8:23, the term apostolos has been understood to mean, 'messengers (apostolos"sent ones") - missionaries of the churches'. The distinction between the use of the term 'apostles' in 2 Corinthians 8:23 with Ephesians 4:11 is that in the first usage they were sent out to join and assist Paul on his foreign missions, whereas in Ephesians 4:11 the context is specifically the local church. 'We would see an apostle as being someone who is moving the church into extension, church planting, crossing frontiers, and embracing significant movements beyond itself' (Frost \& Hirsch 2003:170). Frost and Hirsch (2003:170) advocate for an apostolic office in the church, 'Some will be called to be apostles, but the whole community is to be apostolic (ibid)', but this undermines that the entire community is apostolic. In view is a special leadership gifting as opposed to an apostolic office in the church.

\section{The prophetic equipping function}

The term prophet has in mind the prophetic missionary function of casting a vision and the call to impact and influence. The prophetic call is the call to a simpler and more radical New Testament lifestyle by Christians:

\footnotetext{
We need leaders who are prophets, who communicate God's call to conversion in today's context. This function is important for church's to be able to separate themselves from the old paradigms. Without prophetic leadership, we might be unable to break up and move forward. Prophetic leadership is also related to daring to carry out powerful and sensational symbolic acts. (Jørgensen 2012:70)
}

The prophetic role is the visionary role and the ability to paint the vision before the eyes of the world (cf. Roxbury 1997).

\section{The evangelistic equipping function}

In the New Testament contexts, the evangelists, like Timothy, were closely associated with the mission of the apostles and assisted the apostles in the ministry of proclamation. Alan Hirsch describes what he calls the missional-incarnational impulse of 'going out' and 'going deep'. 'God continues to send the church outward into the world as well as deeper into people's lives and contexts, to send and embed the Gospel' (Frost \& Hirsch 2009:91). In Ephesians 4:7-16, both inward and 'going deep', is expressed by the term oikodome which has the meaning of building up, but 'going out' is expressed by the term oikonomia in 1 Peter 4:10. Missional leadership, oikonomia, is directed at both the nurturing ${ }^{14}$ of the believers and the church and to reach out to the world. 'Mission is the force that gives the body of Christ vibrancy, vitality, purpose and direction' (Van Rheenen [1996] 2014:100). The local church is nurtured and edified as it embraces the call to be a missional church. 'Mission is to the church what blood is to the body. As the body cannot survive without blood, so the church cannot survive without mission' (Van Rheenen [1996] 2014:99).

\section{The pastor and teaching equipping function}

The apostolic task of the church involves identifying church members or elders who have 'the missionary leadership gifting'. One of the roles and functions of such a leader or an elder is to be a servant or steward of God, which includes missions, and to lead the church into missional expression. Paul identifies himself as God's steward in his mission in Ephesians 3:2. The term oikonomia is employed by Paul in Ephesians to indicate the role of Jesus Christ, the apostles and the church in particpating in the mission of God. In the Pastoral Epistles, the term oikonomia has in view the dual function of missions and the missional function in the church. The term is used in 1 Timothy 1:4 for missions or pastoral role and Titus 1:7 to express the elder's leadership role in a church's missional structure. The calling and function of the eldership in the church is to lead a church to fulfil its missional calling. The calling of the church eldership is to lead the church to be a missional and reconciling community. It is the pastor who leads the church to fulfil its obligation in terms of foreign missions ${ }^{15}$.

\section{Conclusion}

The priesthood of all believers has not been effectively realised because a sharp differentiation continues to be made between the clergy and laity in the institutionalised church. The missional church paradigm operates with a church structure in which the institutional and organic church structure functions together in a dynamic unity. The dynamic unity is achieved through the relation of the inward and outward life of the church in a church in which missions is a mark of the church. The church has two church structures,

14. Nurturing, them, is the process of bringing individual Christians and the Christian community as a whole to maturity' (Van Rheenen 1996, 2014:332).

15.As a family we served as missionaries in Burundi. Our sending church, the Reformed Church Wapadrant, had a mission's pastor, a pastor specifically responsible for missions. In a small church the pastor fulfills both functions. 
an inward structure consisting of the relation of $\kappa \eta ́ \rho v \mu \alpha$,

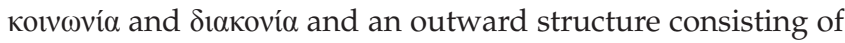

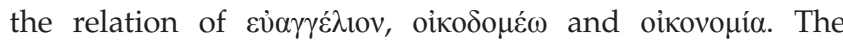
apostle, prophet, evangelist, pastor and teacher of Ephesians 4:11 are missional functions, apostle, prophet and evangelist serving the outward structure, and pastor and teacher serving the inward structure of the church. The inward and outward structures of the church dynamically function together in unity and so there is no sharp differentiation between clergy and laity, institutional and organic church, and the church functions together as a unity to be a missional church.

\section{Acknowledgements Competing interests}

The author declares that he has no financial or personal relationships that may have inappropriately influenced him in writing this article.

\section{References}

Armstrong, J.H., 2010, Your church is too small: Why unity in Christ's mission is vital to the future of the church, Zondervan, Grand Rapids, MI.

Balia, D. \& Kim, K., 2010, Edinburgh 2010: Witnessing to Christ today, Regnum Edinburgh Centenary Series, vol. II, Regnum Books International, Oxford.

Barth, M., 1974, Ephesians: Translation and commentary on chapters, vol. 34A Doubleday \& Company, Inc., Garden City, NY.

Barth, K., 1978, Ensayos teológicos, Herder Publishers, Barcelona.

Engel, J.F. \& Dryness, W.A., 2000, Changing the mind of missions: Where have we gone wrong? InterVarsity Press, Downers Grove, IL.

Frost, M. \& Hirsch, A., 2003, The shaping of things to come: Innovation and mission for the 21st-century church, Hendrickson, Peabody, MA.

Frost, M. \& Hirsch, A., 2009, Re-Jesus: A wild Messiah for a missional church, Hendrickson, Peabody, MA.

Goheen, M.W., 2000, 'As the Father has sent me, I am sending you': J.E. Lesslie Newbigin's missionary ecclesiology, Uitgeverij Boekencentrum, Zoetermeer.

Goheen, M.W., 2011, A light to the nations: The missional church and the biblical story, Baker Academic, Grand Rapids, MI.

Guder, D., 2000, Missional church: A vision for the sending of the church in North America, Eerdmans, Grand Rapids, MI.

Hoksbergen, R., 2011, 'The global economy, injustice, and the church: On being reformed in today's world', S.J. Roels \& S. Nyomi (eds.), Reformed in an age of world Christianity: Ideas for the 21st century, pp. 93-103, Calvin College Press, Grand Rapids, MI.

James, F.A., III, 2013, 'Missional is mission critical', in S.T. Logan, Jr. (ed.), Reformed means missional: Following Jesus into the world, New Growth Press, Greensboro, NC.

Jørgensen, K., 2012, Equipping for service: Christian leadership in church and society, WIPF \& STOCK, Eugene, OR.
Marsh, C., 2005, 'Reconciliation: An ecumenical mission paradigm', in K. Kim, (ed.), Reconciling Mission: The ministry of healing and reconciliation in the church worldwide, Selly Oaks Mission Series, vol. 1, Indian Society for Promoting church worldwide, Selly Oaks Mission Series, vol. 1, Indian Society for Promoting
Christian Knowledge/United Society for the Propagation of the Gospel and Trustees for Methodist Church Purposes, pp.43-61, Cambridge Press, and Trustees
Cambridge.

Newbigin, L., 1989, The Gospel in a pluralist society, Eerdmans, Grand Rapids, MI.

Newbigin, L., 1995, The open secret: An introduction to the theology of mission, Eerdmans, Grand Rapids, MI.

Ott, C., Strauss, S.J. \& Tennent, C., 2010, Encountering theology of missions: Biblical foundations, historical developments, and contemporary issues, Baker Academic, Grand Rapids, MI.

Padilla, R., 2004, 'Introduction: An ecclesiology for integral mission', in T. Yamamori \& C.R. Padilla (eds.), The Local church, agent of transformation: An ecclesiology for integral mission, pp. 19-48, Kairos Ediciones, Buenos Aires.

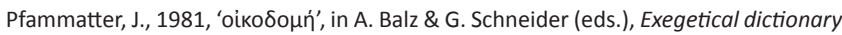
of the New Testament, vol. 2, pp. 495-498, William B. Eerdmans Publishing Co., Grand Rapids, MI

Plummer, R.L., 2006, Paul's understanding of the church's missions: Did the Apostle Paul expect the early Christian communities to Evangelize? Paternoster Biblical Monographs, Paternoster, Milton Keynes.

Pratt, Z., Sills, M.D. \& Walters, J.K., 2014, Introduction to global missions, B\&H Publishing Group, Nashville, TN.

Roldán, A.F., 2004, 'The priesthood of all believers and integral mission', in T. Yamamori \& C.R. Padilla (eds.), The local church, agent of transformation: An ecclesiology for integral missions, transl. Brian Condignly from the Spanish, La ogles local como agent de transformacion, pp. 151-177, Editions Kairos, 2003, Buenos Aires.

Roxburg, A.J., 1996, The missionary congregation, leadership, \& liminality, Trinity Press International, Valley Forge, PA.

Roxburg, A.J., 2009, Introducing the missional church. What it is, why it matters, how to become one, Baker Publishing House, Grand Rapids, MI.

Saayman, W., 2010, 'Missionary or missional?: A study in terminology', Missionalia $38(1), 5-16$

Schultz, K.D., 2009, Mission from the cross. The Lutheran theology of mission, Concordia Publishing House, Saint Louis, MO.

Sills, M.D., 2010, Reaching and teaching: A call to great commission obedience, Moody Publishers, Chicago, IL.

Stephanou's, A.Z., 2010, 'Towards an Arabic political theology: A contextual approach to co-existence and pluralism', in K. Kim \& A. Anderson (eds.), Edinburgh 2010, Mission today and tomorrow, Regnum Edinburgh 2010 Series, pp. 217-221, Oxford Centre for Mission Studies, Oxford.

Stott, R.W., 1979, The message of Ephesians. The Bible speaks today, Inter-Varsity Press, Leicester, England.

Sunquist, S.W., 2013, Understanding Christian missions: Participation in suffering and glory, Baker Publications Group, Grand Rapids, MI.

Taylor, D \& Cho, Y., 2010, 'Tokyo 2010: Analysis and reflection on the global mission consultation', in K. Kim \& A. Anderson (eds.), Edinburgh 2010: Mission today and tomorrow, pp. 304-320, Regnum Edinburgh 2010 Series, UK.

Van Engen, C., 1996, Mission on the way. Issues in mission theology, Baker Books, Grand Rapids, MI.

Van Rheenen, G., [1996] 2014, Mission: Biblical foundations and contemporary strategies, 2nd edn. Zondervan, Grand Rapids, MI.

Visser, P.J., 2011, 'Reformed principles as remaining roots', in S.J. Roels \& S. Nyomi (eds.), Reformed in an age of world Christianity: Ideas for the 21st century, pp. 37-44, Calvin College Press, Grand Rapids, MI.

Wright, C.J.H., 2010, The mission of God's people: A biblical theology of the church's mission, Zondervan, Grand Rapids, MI. 